\title{
An Exploration of Determinants of Entrepreneurial Characteristics, Motivation, and Challenges in Palestine
}

\author{
Maisa Y. Burbar ${ }^{1} \&$ Suzan J. Shkukani ${ }^{2}$ \\ ${ }^{1}$ Lecturer, Business and Marketing Department, Birzeit University, Birzeit — Ramallah, West Bank, Palestine \\ Correspondence: Maisa Y. Burbar, Business and Marketing Department, Birzeit University, Birzeit — Ramallah, \\ West Bank, Palestine.
}

Received: June 10, 2021

Accepted: July 26, 2021

Online Published: August 9, 2021

doi:10.5539/ibr.v14n9p53

URL: https://doi.org/10.5539/ibr.v14n9p53

\begin{abstract}
Being an entrepreneur is becoming an anabranch in the business world. In addition, many young adults are preparing to be entrepreneurs in the future. Worldwide, many intellectuals view entrepreneurship as necessary to small-medium enterprises (SMEs) in general because it is critical to development. Micro, small-medium enterprises (MSMEs) are crucial in Palestine because MSMEs dominate the Palestinian economy.

This study highlights the specific characteristics of entrepreneurship and the factors motivating and challenging people when starting up their enterprises in Palestine and dealing with these challenges and obstacles.

The research method combines qualitative and quantitative tools, each of which was used to study relevant aspects. The qualitative tools used are interviews with the entrepreneurs in Palestine, while the quantitative tool included a designed questionnaire. The collected data was then analyzed using SPSS v 23.

Findings indicated that entrepreneurs in Palestine are self-confident, passionately seeking new opportunities with a good network of professionals, patient, persistent, and determinant, and can adapt to change. The results further highlighted that the most motivational factors behind being an entrepreneur in Palestine include being their boss and increasing income to have a better financial future. However, Lack of savings, political situation, competition, and the fear of risk associated with starting a business is the significant challenges and obstacles they face., Finally, Results indicate that gaining experience, developing business plans, managing financial resources, and motivating employees are the critical factors they have to consider. At the same time, they deal with these challenges and obstacles.
\end{abstract}

Keywords: small business, micro, small-medium enterprises (MSMEs), entrepreneurship, entrepreneur, entrepreneurial characteristics, entrepreneurial motivation and entrepreneurial challenges, Palestine

Paper Type: Research Paper

\section{JEL Classification: M12, M19}

\section{Introduction}

Today's economy gained the increasing attention of small and medium businesses worldwide. As a result, the country's economies are affected highly by solid small and medium enterprises (SMEs) while also contributing to the gross domestic product (GDP) by reducing the level of unemployment, reduction in poverty levels, and promoting entrepreneurship activity (Sitharam \& Hoque, 2016).

Defining an SME can be challenging, as the term includes a wide range of definitions globally. A quick review of the literature reveals no universal consent definition of these enterprises (Chittithaworn, Islam, Keawchana, \& Yusuf, 2011). Countries and businesses use their judgment when defining small enterprises. The most used criteria are the number of employees and economic measures based on the financial statements of the enterprise and the value of its assets (Berisha \& Pula, 2015; Teng, Bhatia, \& Anwar, 2011). The literature did not agree on a particular definition for SMEs, as various authors provided various explanations (Bundaleska, Dimitrova, \& Nikolovska, 2011). However, it is generally related to some criteria such as magnitude, the number of employees, capital, etc. (Abor \& Adjasi, 2007; Asunka, 2017).

Kuzieva (2017) stated that many people were encouraged to open their businesses in the past; small enterprises were created. As for the present, the creation of small enterprises is often inaugurating by large companies that 
accredit them to conduct certain types of products or establish close ties with the market. Several researchers have acknowledged entrepreneurship as essential to small business enterprises (Kongolo, 2010; Ligthelm, 2008; Sebikari, 2014). Kongolo (2010) suggested that both small businesses and entrepreneurship form the heart of economic development by absorbing productive resources at all economic levels. Rafi, Arzu, Khan, ul Haq, and Kashif (2013) mentioned that starting a new venture is the most form of entrepreneurship.

In the Palestinian context, the Palestinian National Authority has not yet established a definition of small and medium-sized enterprises, which is one objective of this study; SMEs were defined based on the employment and annual revenues index developed by the Palestinian Monetary Authority (PMA). SMEs are enterprises with less than 25 employees and less than US\$ 7 million in total revenues (Baidoun, Lussier, Burbar, \& Awashra, 2018).

According to Wilson (2020), The Palestinian economy is mainly comprised of Micro SMEs. (MSMEs). They have an essential role in the economy, employing the most significant number and contributing significantly to its overall economic welfare. MSMEs in Palestine account for $99.8 \%$ of all enterprises, as mentioned in the Palestinian Central Bureau of Statistics (2019).

The definition used by PCBS, 2018, as cited in Wilson (2020) that $90.5 \%$ of companies are micro (with fewer than five employees), $89 \%$ are small (5-19 employees), and 1\% are medium (20-99 employees). Large businesses thus employ about $0.01 \%$ of the total labor force. MSMEs are typically family-owned businesses usually managed by a family member.

The MENA Catalyst Foundation report (2020) indicates that 80 percent of MSMEs are dependent on their owners' personal savings to maintain operations. MSMEs are the basis of the Palestinian economy and have displayed their flexibility even in the most challenging periods, during political instability, imposed closures, and outright external attacks.

As essential as entrepreneurship has become, it takes years to boost a healthy entrepreneurial economic system that contributes to the overall GDP for many reasons. Among are that approximately 90 percent of MSMEs cannot obtain loans, the scarcity of resources deep routed within Palestine, and the high rates of MSMEs within the informal sector without the legal registration needed to secure finance.

The Economic Surveys series in Palestine revealed that 145,628 enterprises were operating in the private and non-government sectors in 2019, with a growth rate of $3.8 \%$ compared with 2018 . These enterprises are working in different economic sectors. These enterprises employed 549,740 persons in the various sectors based on the Palestinian Central Bureau of Statistics, (2019).

According to Doing Business (2020), Palestine's ranked 117 out of 189 countries in terms of overall ease of doing business; it is caused by negative factors such as employment costs, legal rights, tax regulations, and finance access. The West Bank and Gaza Strip's overall position is low compared to its nearest neighbors, with the United Arab Emirates having minor restrictive procedures in place. It should be noted that Palestine has improved its position in recent years, rising from 140 in 2016 to 117 in 2019.

This study aims to explore Small Medium Enterprises SMEs' entrepreneurship profile in Palestine and identify the entrepreneurial characteristics and traits, determine factors that influence the level of motivation among the entrepreneurs in Palestine. Furthermore, to examine the constraints posing challenges on entrepreneurs in Palestine.

The research will, therefore, answer the following questions that support the study objectives stated above:

1. what entrepreneurial characteristics do the Palestinian entrepreneurs Possess?

2. What motivates Palestinian people to take financial risks, leave the safe environment of a job to pursue an uncertain future, and make the personal sacrifices required to start and grow a business?

3. What are the problems and challenges that face Palestinian entrepreneurs throughout their journey?

4. How can a Palestinian entrepreneur deal with the challenges /obstacles that affect the startup and growth of their business?

\section{Theoretical Framework}

\subsection{Entrepreneur and Entrepreneurship}

Several studies discussed entrepreneur and entrepreneurship since it first emerged around 1800 by Jean-Baptiste Say, a liberal French economist, and businessman. So far, the definition of an entrepreneur and what constitutes entrepreneurship remains blurry and ambiguous. However, with time this image is gradually adjusting its clarity. 
Nimalathasan (2008) argues that the term "Entrepreneur" is defined in diverse ways, yet there is no fixed agreement on the exact skills and abilities that shape a successful entrepreneur. As a concept, it varies from one country to another and within different periods; moreover, economic development plays a role. Several studies view the entrepreneur as a self-employed person established in a pleasant environment and was not born this way. Others conveyed that an entrepreneur and enterprise builders perceive opportunities as no one has done before. They possess qualities that help them commence and continue running their enterprises while enjoying profits as rewards in return for the associated risk (Kilby, 1971).

A broader interpretation stipulates, "It is all about creativity and innovation. Innovation in the view of opportunities and risks, new approaches to problem-solving, a strategic plan to recognize opportunities and risks, and minimize the risks can occur. Planning and creating a strategy is one of the important parts of the entrepreneurship concept as well, and it supports generating business success. The major factor in entrepreneurship is the entrepreneur's role who takes complete responsibility for the business's operation." (Dollinger, 1995).

There is a focal point that intersects in almost all definitions, that entrepreneurship is "a kind of behavior that includes initiative-taking, the organizing and reorganizing of social and economic mechanisms to turn resources and situations to practical account, and the acceptance of risk or failure." (Yimamu \& Nadire, 2018).

A similar definition by (Hisrich, Peter, \& Shepherd, 2005) expresses the following: "Entrepreneurship, the entrepreneurial function, can be conceptualized as the discovery of opportunities and the subsequent creation of new economic activity, often via the creation of a new organization." (Reynolds et al., 2005), continues to highlight an integral and inevitable part that cannot be detached from the concept of entrepreneurship and is always considered cognitive. Cognitive factors are a built-in segment of entrepreneurship, "the ability to understand complex ideas, adapt effectively to the environment, learn from experience, engage in various forms of reasoning and to overcome obstacles with careful thought." (Greenberg \& Baron, 2008) to elaborate, Holt (2000) said that an entrepreneur is a person who incubates new ideas, starts new ventures, and ultimately adds value to society.

Moreover, the entrepreneur is "an individual who is alert to opportunities and is capable of identifying suppliers and customers and acting as an intermediary where the profit arises out of the intermediary function." (Deakins, Freel, \& Mason, 1999).

According to (Koltai, 2016), an entrepreneur "is a person with the vision to see a new product or process and the ability to make it happen.

\subsection{Entrepreneurial Characteristics}

Entrepreneurship is all about individuals. Of course, other components, including good economic circumstances, marketing, and finance, are essential, but alone without the entrepreneur, nothing can be done.

Shaver and Scott (1992) state that "we need a person whose mind all of the possibilities come together, who believes that innovation is possible, and who has the motivation to persist until the job is done."Researchers in the scope of entrepreneurship try to determine what personality characteristics differentiate entrepreneurs from non-entrepreneurs and managers in large firms. At the same time, they distinguished between successful and unsuccessful entrepreneurs (Naffziger, Hornsby, \& Kuratko, 1994).

Hines (2004) believes that there are at least nine characteristics that he values: energy level, ego, courage, enthusiasm, desire to make money, Creativity, resourcefulness, tenacity, and leadership qualities.

(Gürol \& Atsan, 2006) discussed the trait model; this model assumes that entrepreneurs have specific distinctive characteristics, attitudes, and values that motivate them and distinguish them from others in a similar way

(Yimamu \& Nadire, 2018) said that "being different is the first typical characteristic of entrepreneurs.

Carsrud and Brännback (2009) said that Entrepreneurs see opportunities everywhere, notice something that could be better, put plans and make actions, and have the vision.

There is no agreement among the scholars on the entrepreneur's characteristics. An entrepreneur should have several notable characteristics that help them become successful. They include several traits: the desire for responsibility, risk-taking, self-confidence, high energy, and emotional stability (Olm \& Eddy, 1985; Zimmerer \& Scarborough, 1998; and Fong, Jabor, Zulkifli, \& Hashim, 2020).

Berglann, Moen, Røed, and Skogstrøm (2011) believe that factors such as Professional competencies, family capabilities, gender are some of the characteristics that affect people's decision to become entrepreneurs or not. 
Knörr, Alvarez, and Urbano (2013) stated that the probability of becoming an entrepreneur increase if the person has characteristics as Creativity, risk-taking, and independence. Kozubíková, Belás, Bilan, and Bartoš (2015) mentioned that some of the most important personal traits for the entrepreneur are courage, self-reliance, responsibility, determination, perseverance, proactive approach, Creativity.

Nimalathasan (2008) mentioned, "Entrepreneurs place a high value on ambition, achievement, reliability, responsibility, hard work, competence, optimism, innovation, aggressiveness, honesty, Creativity, social recognition, and growth. Some other characteristics are insight, brainstorms, deceptions, ingeniousness, and resourcefulness". Moreover, Nimalathasan (2008) said that an entrepreneur should be a risk-taker, self-confident, goal setter, hard worker, and accountable. In addition, entrepreneurs are pragmatic about working hard, driving toward commensurable results, having outstanding conceptual abilities, and are generally emotionally steadier. Of course, it is unnecessary, but the more a person has these traits, the more excellent their opportunity to become an entrepreneur.

\subsection{Entrepreneurial Motivating Factors}

Motivation is a crucial factor that inspires people to start and sustain new ventures, so it is vital to understand what and how people are motivated (Kuratko, Hornsby, \& Naffziger, 1997).

McClelland and Mac Clelland (1961), one of the first researchers about motivational factors, emphasized the need for achievement and explained it as a strong desire to do things in the best way or better than others.

Entrepreneurial motivating factors can either be internal or external forces (Kuratko et al., 1997; Robichaud, McGraw, \& Alain, 2001). For example, Hussain and Yaqub (2010) mentioned that entrepreneurs in urban areas are generally motivated by their internal needs, while entrepreneurs in rural areas are usually motivated by their external needs.

Researchers also addressed these motivational factors as push (negative) and pull (positive) factors; as mentioned earlier, the push factors are considered external forces while the pull factors are considered internal forces. For example, unemployment is an external force that pushes the person to act; conversely, when we talk about pull factors, imagine someone who dreams of having his own business. It is a clear example of the internally driven motive (Driessen \& Zwart, 2006).

The pull factors are divided into three different needs: achievement, independence, and financial freedom. On the other hand, the push factors can be classified as unemployment, dissatisfaction caused in workplace competitive situations, or even changing lifestyles (Nel, Maritz, \& Thongprovati, 2010).

According to Barba-Sánchez and Atienza-Sahuquillo, (2012), three particular motives distinguish entrepreneurs: the need for achievement, competition, and demand for independence, with other factors such as the need for power, ambiguity tolerance, innovation, and proactiveness or persistence.

Yimamu and Nadire (2018), in research Entrepreneurship and Entrepreneurial Motivation, mentioned that the motivating factors behind the choice to be an entrepreneur were the need for achievement, desire for independence and financial freedom, endless love for doing something great, unemployment issue, and a found business opportunity in the market. Two of the interviewees were foreigners. They said that what motivated them most was self-employment because the employment situation in Finland was not good for them as foreigners who do not have Finnish language skills.

The literature emphasizes the importance of an internal locus of control, which indicates that the person believes their actions lead to outcomes and not luck or chance (Barba-Sánchez \& Atienza-Sahuquillo, 2012). Other factors such as risk-taking, tolerance for ambiguity, self-efficacy, and goal setting also can influence the entrepreneurial process (Abdul Halim, Ab Aziz, \& Zakaria, 2010).

Knörr et al. (2013) said that creativity, risk-taking, and independence are the main motivational factors that raise the odds of becoming an entrepreneur and reduce the odds of becoming an employee.

Almeida, Ahmetoglu, and Chamorro-Premuzic (2014) discuss that entrepreneurial individuals are characterized mainly as adventurists and creative. They are more individually oriented; they have greater individual responsibility and effort.

In this framework, Gomezelj and Kušce (2013) indicate that risk-taking, self-efficacy, and independence are the most critical factors affecting a businessman's performance.

In general, several factors have been found to motivate entrepreneurs, including the desire for autonomy, family security, self-fulfillment, growth, financial gain, and opportunity recognition (e.g., Benzing, Chu, \& Szabo, 2005). Most researchers agreed that the key motivators are the desire for financial security and lack of good job 
opportunities (Yalcin \& Kapu, 2008).

\subsection{Entrepreneurial Challenges}

According to Sean Bryant (2020), 90\% of startups fail, which indicates the enormous challenges entrepreneurs face through their journey. Yimamu and Nadire (2018) mentioned in their study entitled Entrepreneurship and Entrepreneur motivation that there are several challenges facing entrepreneurs such as developing the business idea, raising capital, creating a business team, finding skilled employees, marketing and customers, understanding and dealing with competitors, and keeping up with change.

Fong et al. (2020) divided the fundamental challenges into three main challenges: Internal, External, and Unforeseen challenges separating the internal challenges into three different challenges; developing a business idea and vision, finding the right business location, and raising capital for a startup; on the other hand.

Fong et al. (2020) said that the external challenges are environmental factors dividing external challenges into two main challenges: dealing with competitors and finding good customers. Moreover, Fong et al. (2020) said that there are unforeseen challenges. They might be one of the most significant challenges because they are unexpected such as changing government policies, bad debts from customers, and unexpected lawsuits.

Benzing et al. (2005) revealed that obtaining capital is a challenge for owners of small and medium-sized enterprises in developing and transition economies. Without money, the success and growth of the business are limited. The results of Hefer, Cant, and Wiid (2015), in response to the significant challenges, were that getting funding was the first challenge, followed by providing security to banks, then lack of government support.

Zimmerman and Chu (2013) emphasized the challenges that face entrepreneurs in developing countries, and one of the biggest challenges was the instability and bureaucratic business context. For example, in Africa, entrepreneurs struggle with laws governing private enterprises. As in Kenya, the challenges were the weak economy, competition, and undependable employees.

\section{Methodology}

To meet the objectives of the study, which is exploring the entrepreneurship profile of Small Medium Enterprises SMEs in Palestine, and to identify the entrepreneurial characteristics and traits, in addition to determining the motivating factors that led their entrepreneurial journey, along with the challenges they faced, the research was divided into three stages: the first is the preliminary study through the literature review, then, designing the questionnaire as a measuring instrument supported by face-to-face interviews, and the third stage which provided the reader with a finding of analytical results.

\subsection{Data Collection and Sampling}

The study is designed of two different research methods: qualitative and quantitative research.

The qualitative tools are based on interviews with entrepreneurs in Palestine to investigate their characteristics, motives, challenges based on their unique personal experience in their own words.

As for the quantitative tool, a special questionnaire was developed for this study to determine the motivations and challenges for starting your own business. The questionnaire was first piloted by Business owners and based on their feedback, and some items were reworded for clarity.

The sampling population consists of entrepreneurs in Palestine using a simple random sample technique; 180 questionnaires were distributed, 150 respondents returned correctly filled questionnaires for data analysis. Besides, the data were obtained through face-to-face interviews with 22 entrepreneurs.

After completion of the data entry, data were exported into SPSS for statistical analysis. Statistical tools such as mean, range, and percentage have been used to analyze quantitative data. In addition, other techniques were applied, frequency distributions, cross-tabulation, and descriptive analysis to guarantee that the instrument used measures the concept thoroughly.

\subsection{Research Design}

The questionnaire was divided into four main parts: The first part tackles the demographic data such as (age, gender, education profile, and experience) that are crucial for the study. The second part deals with the business characteristics such as (a type of business, establishment, financing, ownership, and number of employees). The third part addresses the entrepreneurial characteristics, while the fourth section deals with motives, challenges that face entrepreneurs, and how to overcome such challenges, obstacles, and obstacles' performance.

Questions constructed within The Likert scale type questions were presented in a statement using different distracters based on each question's objective. Therefore, respondents were required to select one of five options: 
strongly disagree, disagree, neutral, agree, and strongly agree. In addition, the respondent was required to choose one of three options: very difficult, medium difficulty, little difficulty, and respondents were required to select one of four options, namely: below average, average, successful, very successful. Therefore, respondents were required to check and rank what describes them by giving one to the most. Another type, Yes /No type questions, where the respondent must answer only with a yes or no, and respondents were required to select one of three options: decreased, increased, stayed the same.

Semi-structured interviews were conducted to support the main findings of the study. The questions used were open-ended questions that mainly asked how this person became an entrepreneur, his motives, eagerness, and intentions.

\section{Findings}

\subsection{Interviews Results}

Interviews were conducted with 22 new entrepreneurs, 19 females and 3 males. Their ages ranged between 20 and 29 years. Most of them hold bachelor's degrees, and their experience years were between 1 to 3 years established businesses between 2016- 2019 with personal financing, while some with help from their families, and most of them had between 1-9 employees. The type of business they specialize in is producing \manufacturing, services, and Handicraft, establishing their enterprise alone, and 2 of them established with a business associate.

It was noted that the interviewees are self-motivated; the most significant characteristic that was mentioned by all of the entrepreneurs was patience and persistence, creativity, innovative skills, self-confidence, dynamic hard worker, and adapting to change. Without a doubt, all entrepreneurs ensured their personality and characteristics helped to choose to start the entrepreneurial.

According to interviews, motivating factors behind choosing to be an entrepreneur include the desire for independence and financial freedom and a good opportunity in the market. However, most entrepreneurs mentioned that the most common motivating factor was their desire to do something they love and dream of achieving, having experience in the field, and being their bosses.

As concluded from the interviews, the results are highly in line with the scientific theories presented in the literature and support the survey results.

As for the Challenges faced during the entrepreneurial process, the interviewees' challenges included the lack of savings capital and the difficulty to get loans. Moreover, the weak economic environment, the high level of competition, government regulation/bureaucracy, and the political situation. The coronavirus (COVID-19) added up to the challenges and worked hard, and for a long time, most interviewees mentioned every day.

For the question "what helped you the most when facing and overcoming the challenges and obstacles during the entrepreneurial process?"

The response showed the importance of managing financial resources, creating a business plan, and studying and gaining experience.

To summarize, "Never giving up easily" is the sentence repeated most frequently; this shows the importance of committing, sticking to it, and fighting for it until success is achieved in the entrepreneurial process.

\subsection{Survey Results}

\subsubsection{Demographic Information}

The demographic profile of the respondent's group is presented in Table 1(Demographic Data). It is clear that the vast majority (75.3) of respondents were male (113 out of 150$)$, while only $22 \%$ were females; in terms of respondent entrepreneurs' age, almost $39.3 \%$ of them were between 40 and 49 , followed by respondents between 30 and $39(24 \%)$. Furthermore, the results reveal that $34 \%$ of the respondents have bachelor's degrees.

Moreover, $30 \%$ of the respondent already had a small business with less than high school. Finally, in terms of experience, measured by years of work for this study, the Survey showed that most businesses (44\%) had experienced between 3 and 5 years, followed by (18.7\%) with eight years and above. 
Table 1. Demographic Data

\begin{tabular}{|c|c|c|}
\hline Age & Frequency & Percent \\
\hline $20-29$ & 29 & 19.3 \\
\hline 30_39 & 36 & 24.0 \\
\hline $40 \_49$ & 59 & 39.3 \\
\hline $50 \_59$ & 22 & 14.7 \\
\hline 60 and over & 4 & 2.7 \\
\hline Gender & Frequency & Percent \\
\hline Male & 113 & 75.3 \\
\hline Female & 33 & 22.0 \\
\hline Experience & Frequency & Percent \\
\hline From 1 to less than 3 years & 19 & 12.7 \\
\hline From 3 to less than 5 years & 66 & 44.0 \\
\hline From 5 to less than 8 years & 25 & 16.7 \\
\hline 8 years and above & 28 & 18.7 \\
\hline Educational level & Frequency & Percent \\
\hline Less than High School & 45 & 30.0 \\
\hline High school & 18 & 12.0 \\
\hline Diploma & 24 & 16.0 \\
\hline Bachelor's degree & 51 & 34.0 \\
\hline Higher education & 8 & 5.3 \\
\hline
\end{tabular}

The characteristics of the businesses are presented in Table 2(Business Characteristics). As for the sample, most of the businesses owned by the entrepreneurs surveyed were productive $\backslash$ Manufacturing-based businesses $(27.3 \%$,$) , the other category, which is (26.7 \%)$, were service-based businesses, and the others are handicraft technicians and others.

Most small businesses were established between 2006 and 2010 (37.3\%) and (20.7\%) between 2011 and 2015. $44 \%$ of the businesses were established through loans (bank financing), $31.3 \%$ of personal savings. $48.7 \%$ with a business associate, and $45.3 \%$ established their business alone. As for the number of employees, (37.3\%) had between $1-9$ employees, 34\% employed 10-19, finally, as for the Project ownership, $50 \%$ of respondents were independently owned.

Table 2. Business characteristics

\begin{tabular}{|c|c|c|}
\hline \multirow{2}{*}{\begin{tabular}{l|l}
\multicolumn{2}{|c}{ Your enterprise is described as } \\
& Service
\end{tabular}} & Frequency & Percent \\
\hline & 40 & 26.7 \\
\hline Productive $\backslash$ Manufacturing & 41 & 27.3 \\
\hline Handicraft & 25 & 16.7 \\
\hline Technician $\backslash$ technology & 20 & 13.3 \\
\hline Other & 24 & 16.0 \\
\hline Year of establishment & Frequency & Percent \\
\hline $2016-2019$ & 27 & 18.0 \\
\hline $2011-2015$ & 31 & 20.7 \\
\hline $2006-2010$ & 56 & 37.3 \\
\hline $2001-2005$ & 22 & 14.7 \\
\hline Before 2000 & 12 & 8.0 \\
\hline How did you finance your Project & Frequency & Percent \\
\hline Personal savings & 47 & 31.3 \\
\hline Bank loan & 66 & 44.0 \\
\hline Other & 36 & 24.0 \\
\hline Number of employees & Frequency & Percent \\
\hline None & 26 & 17.3 \\
\hline $1-9 \quad$ employees & 56 & 37.3 \\
\hline 10-19 employees & 51 & 34.0 \\
\hline 20-29 employees & 13 & 8.7 \\
\hline 30-40 employees & 4 & 2.7 \\
\hline $\begin{array}{l}\text { Did you establish the enterprise alone or with } \\
\text { a business associate }\end{array}$ & Frequency & Percent \\
\hline Alone & 68 & 45.3 \\
\hline With a business associate & 73 & 48.7 \\
\hline
\end{tabular}




\begin{tabular}{|l|l|c|c|}
\hline & Other & 9 & 6.0 \\
\hline \multicolumn{1}{|l|}{ Project ownership } & Frequency & Percent \\
\hline \multirow{2}{*}{} & Personal property & 75 & 50.0 \\
\cline { 2 - 4 } & Rent & 72 & 48.0 \\
\cline { 2 - 4 } & Other & 2 & 1.3 \\
\hline
\end{tabular}

\subsubsection{Entrepreneurial Characteristics}

As for the entrepreneurs' characteristics, as in Figure 1 entitled (Entrepreneurial characteristics), respondents were asked to choose and rank from 12 characteristics, the most important ones describing them where number one is essential. Then, the mean score and standard deviation were computed for each item.

Results show that the most significant common characteristic with the highest mean is self-confident (8.08), followed by passionately seeking new opportunities (7.54), followed by a good network of professionals (7.03), patience and persistence (6.91), adapts to Change (6.58), and has Determination (6.27).

The other characteristics, such as creativity, innovative skills, and dynamic, were that the hard worker got a lower score (6.17, 6.14 respectively). The least characteristic was (Lead by example), with a mean of 5.68.

The results presented by the entrepreneurs are in line with the scientific theories that describe entrepreneurial characteristics.

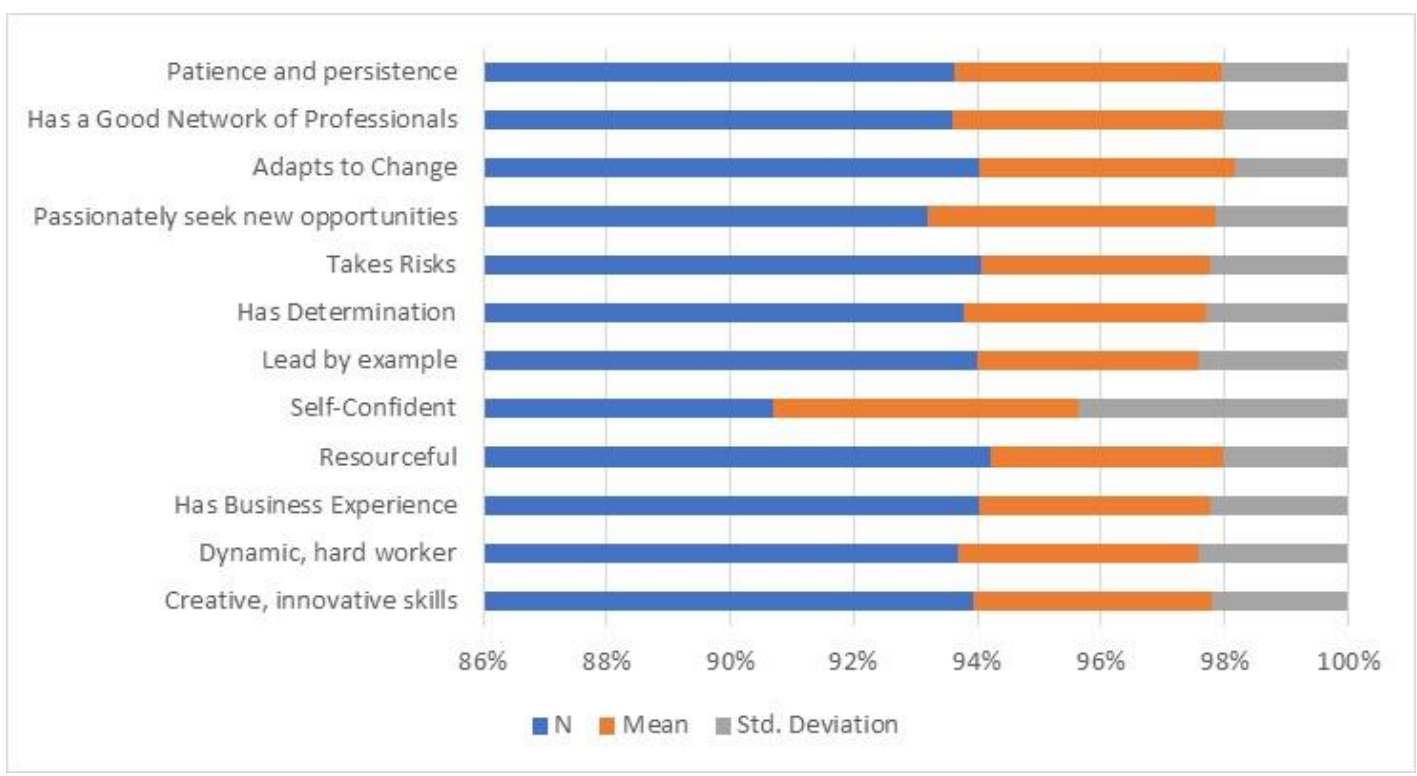

Figure 1. Entrepreneurial characteristics

\subsubsection{Motivation for Starting an Own Business}

In this section, respondents were asked to provide their views on motivation on a scale of strongly agree, agree, neutral, disagree, and strongly disagree. The mean score and standard deviation were computed for each item. Respondents were asked to rate 14 motivating factors for owning a business. Table 3 entitled) Motivational factors show that the two most important reasons to become a business owner were "to be my own boss" (mean of 4.27) and "to increase my income" (mean of 4.07).

Other essential reasons included "to take advantage of my creative talent, innovation "(mean of 3.98), "to provide employment "(mean of 3.93) "for my own satisfaction and growth" (mean of 3.89) and enjoy taking a risk "(mean of 3.87). The lowest rated factors among those presented were "follow the example of someone I admire" (mean of 3.28), "to build an Entrepreneurial family culture," (mean of 3.45). These findings again are in line with the literature reviews and scientific theories. 
Table 3. Motivational factors

\begin{tabular}{|l|r|r|}
\hline Motives & Mean & \multicolumn{1}{|c|}{ Std. Deviation } \\
\hline I want to be my own boss & 4.27 & .791 \\
\hline I want to be Responsible for decision & 3.63 & .901 \\
\hline I want to provide employment & 3.93 & 1.030 \\
\hline I want to build a business to pass on & 3.52 & 1.021 \\
\hline I want to take advantage of my creative talent, innovation & 3.98 & 1.033 \\
\hline To realize my dream & 3.85 & 1.028 \\
\hline To be able to use my past experience and training & 3.68 & .877 \\
\hline I enjoy taking risk & 3.87 & .994 \\
\hline I want to invest personal savings & 3.81 & 1.026 \\
\hline I like to build an Entrepreneurial family culture & 3.45 & 1.359 \\
\hline I want to Increase my prestige and status & 3.69 & 1.100 \\
\hline I want to increase my income & 4.07 & 1.221 \\
\hline Follow the example of someone that I admire & 3.28 & 1.050 \\
\hline I look for my own satisfaction and growth & 3.89 & 1.112 \\
\hline
\end{tabular}

\subsubsection{Challenges and Obstacles in Starting up a Business}

Respondents provided their view on challenges and obstacles on a scale ranging from very difficult, medium difficulty, and little difficulty to the challenges faced during the entrepreneurial process. Respondents were asked to rate 11 challenges in terms of their difficulty.

The mean score and standard deviation were computed for each item. Results presented in Table 4, entitled the challenges and obstacles in starting a small business, indicate that a "Lack of savings" was rated as the most challenging challenge (mean of 2.43), followed by "political situation "(mean of 2.35), "too much competition" (2.34), and "The fear of risk associated with starting a business" (2.33). Other medium difficulties included" Weak economic environment" (2.31) and "Lack of business experience" (2.19). The challenges and obstacles that rated little difficulty were related mainly to" the fear of failure was a problem to me "(2.02), "Unsafe location" (2.09), and "Government regulation/bureaucracy posed an obstacle to me (2.10).

Table 4. Challenges and obstacles In Starting up a Business

\begin{tabular}{|c|c|c|}
\hline Challenges or obstacles & Mean & Std. Deviation \\
\hline Lack of savings was a major factor that posed a challenge to me & 2.43 & .680 \\
\hline I faced difficulty in obtaining bank finance & 2.12 & .578 \\
\hline Lack of business experience & 2.19 & .789 \\
\hline The fear of risk associated with starting a business & 2.33 & .764 \\
\hline The Fear of failure was a problem to me & 2.02 & .773 \\
\hline Weak economic environment posed a threat to me & 2.31 & .657 \\
\hline Convincing others of my idea, finding right partners & 2.18 & .751 \\
\hline Too much competition was a threat & 2.34 & .693 \\
\hline Government regulation/bureaucracy posed an obstacle to me & 2.10 & .663 \\
\hline Unsafe location & 2.09 & .843 \\
\hline Political situation posed a threat to me & 2.35 & .705 \\
\hline
\end{tabular}

\subsubsection{How the Entrepreneurs Avoid or Deal with the Challenges and Obstacles}

When there are challenges, there will be a way to overcome them. For the question, "How did you deal with the challenges and obstacles that face you at work?" Respondents were asked to rate the best way they dealt with the challenges and obstacles they faced by rate number 1 to the most one.

Figure 2 (How the entrepreneurs avoid or deal with the challenges and obstacles) shows that $42.7 \%$ of the respondents rated "I had to arrange financial resources" as the prime way to handle the challenges, followed by $42 \%$ of respondents who stated," I need to study and gain experience." The third way to take the challenge was with a $40 \%$ rate said, "I had to create a business plan" The fourth way was "I had to manage employees in more motivating ways," with a percent of 27.3. Finally, the fifth way was asking for professional counseling with a percent of $25.3 \%$. 


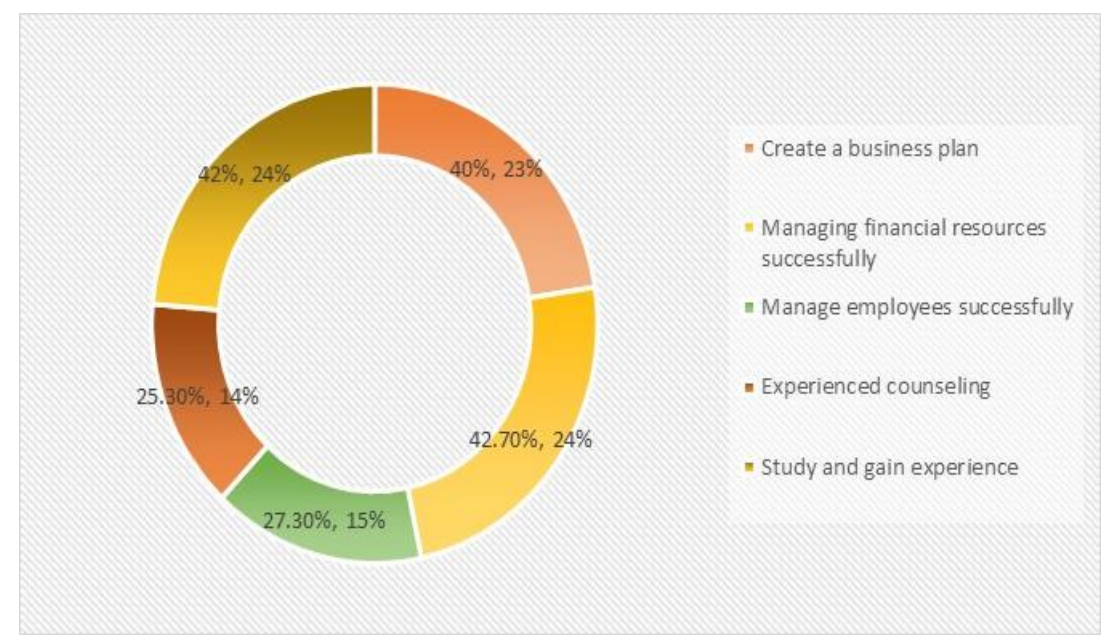

Figure 2. How the entrepreneurs avoid or deal with the challenges and obstacles

\subsection{Cross Tabulation Analysis}

This section focuses on two parts. The first part studies the relationship between ages and how the entrepreneur finances their projects, and the second part focuses on studying the relationship between educational level and business success.

Table 5 (How did you finance your project) below showed the relationship between ages and project financing; 47 respondents financed their projects from their savings; moreover, 21 were aged between 40 to 49 years old. Moreover, 66 respondents depend on a bank loan, 22 of them aged between 30 to 39, followed by 17 aged between 20 to 29 years old. The other remaining respondents depend on other sources of financing.

Table 5. How did you finance your project* Age Cross tabulation

\begin{tabular}{|c|c|c|c|c|c|c|c|}
\hline & \multicolumn{5}{|c|}{ Age } & \multirow[b]{2}{*}{ Total } \\
\hline & & $20-29$ & $30 \_39$ & $40 \_49$ & $50 \_59$ & $\begin{array}{c}60 \text { and } \\
\text { over }\end{array}$ & \\
\hline \multirow{4}{*}{$\begin{array}{ll}\text { How did you } \\
\text { finance } \\
\text { project }\end{array}$} & $\begin{array}{l}\text { Personal } \\
\text { savings }\end{array}$ & 12 & 7 & 21 & 4 & 3 & 47 \\
\hline & Bank loan & 17 & 22 & 11 & 15 & 1 & 66 \\
\hline & Other & 0 & 7 & 26 & 3 & 0 & 36 \\
\hline & & 29 & 36 & 58 & 22 & 4 & 149 \\
\hline
\end{tabular}

The result between the educational level and business success is shown in Table 6 (Education level Cross tabulation). Using a four-point Likert scale, with one as below average, two as average, three as successful, and four as very successful, business owners were asked how they would describe their business success.

It was noted that 53 of the respondents stated that the business is successful, where 26 of them hold bachelor's degrees. Moreover, 37 respondents said their business is very successful, 13 of them with bachelor's degrees, and 15 with less than high school. In addition, 39 of the respondents describe their business as average, where 15 of them with less than high school and 10 with high school, finally 16 describe their business below average, 9 of them hold diploma certificates.

Table 6. How would you describe your business success? * Education level Cross

\begin{tabular}{|c|c|c|c|c|c|c|c|}
\hline & \multicolumn{5}{|c|}{ Education level } & \multirow[b]{2}{*}{ Total } \\
\hline & & $\begin{array}{c}\text { Less than High } \\
\text { School }\end{array}$ & $\begin{array}{c}\text { High } \\
\text { school }\end{array}$ & Diploma & $\begin{array}{c}\text { Bachelor's } \\
\text { degree }\end{array}$ & $\begin{array}{c}\text { Higher } \\
\text { education }\end{array}$ & \\
\hline How would you & Below average & 4 & 1 & 9 & 2 & 0 & 16 \\
\hline describe your & Average & 15 & 10 & 3 & 9 & 2 & 39 \\
\hline business success? & Successful & 11 & 5 & 10 & 26 & 1 & 53 \\
\hline & Very successful & 15 & 2 & 2 & 13 & 5 & 37 \\
\hline Total & & 45 & 18 & 24 & 50 & 8 & 145 \\
\hline
\end{tabular}




\subsection{Are You Satisfied with Your Business Success?}

In response to a question regarding the extent of satisfaction with business success (using yes and No questions), figure 3 showed that $78 \%$ were satisfied and $21 \%$ were unsatisfied.

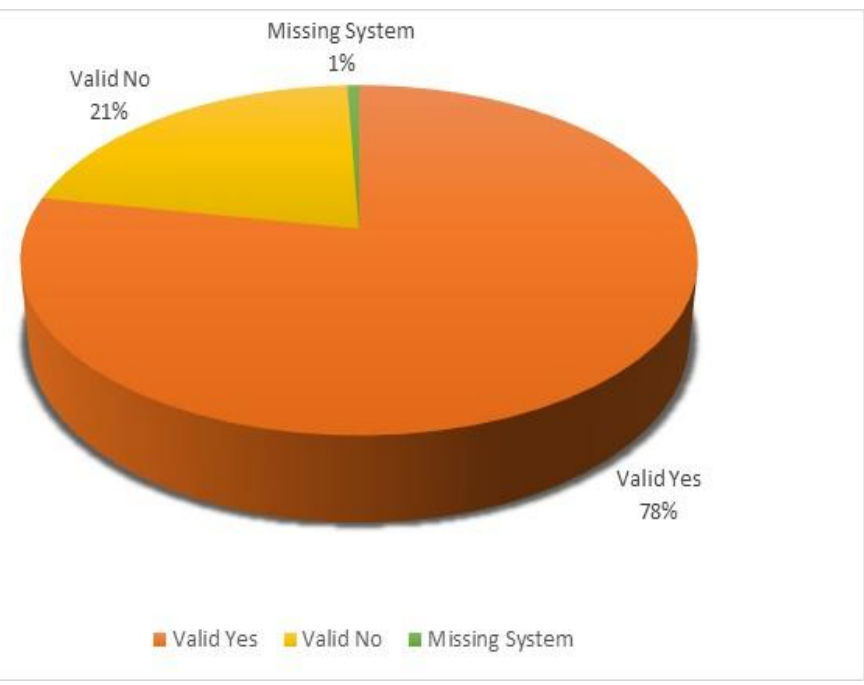

Figure 3. Are you satisfied with your business success?

In addition, when we asked the entrepreneurs who were dissatisfied with their project's success if they regret starting their business? 13\% of the respondents said yes, they regret starting this business, whereas $8 \%$ said no. They did not regret starting their business, and $79 \%$ of the respondents prevented answering these questions, as shown in figure 4.

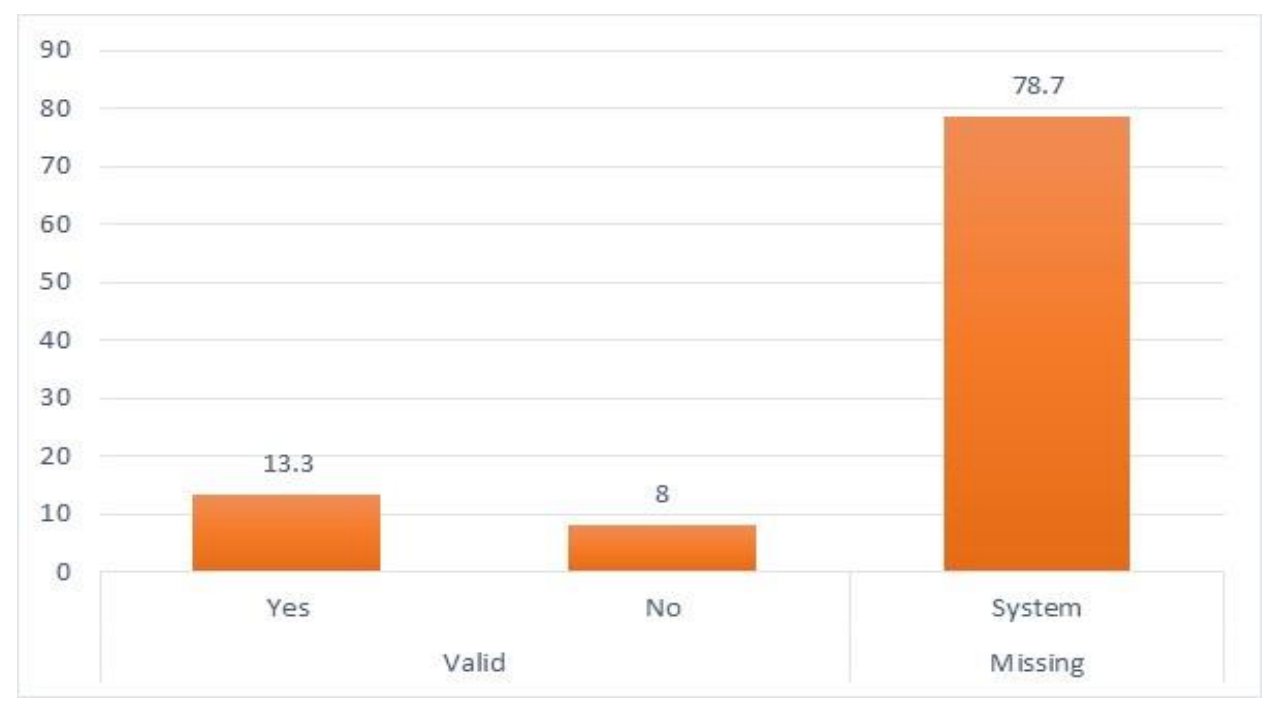

Figure 4. Do you regret starting your business?

Moreover, the last question was about their sales, profit, and market share if they increased, decreased, or stayed the same. 41.3 noted businesses had an overall increase, where $39.3 \%$ of the business had decreased, while $16 \%$ stayed the same, as shown in figure 5 . 


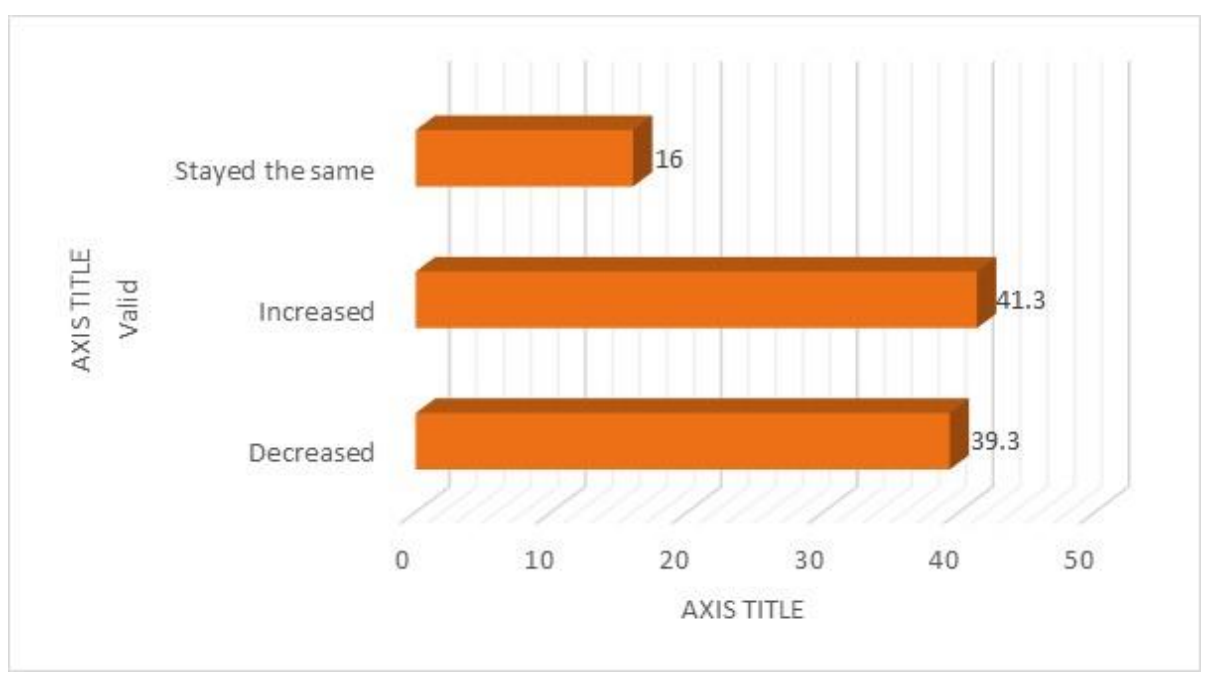

Figure 5. How would you describe your sales, profit, and market share?

\section{Conclusion}

This research aims to provide real insight into the motivating and challenging factors that face SMEs in Palestine while exploring the entrepreneurship profile and their entrepreneurial characteristics and traits.

As the research paper's introduction states, Entrepreneurship is imperative for small business enterprises (Nangoli, Turinawe, Kituyi, Kusemererwa, \& Jaaza, 2013; Reynolds et al., 2005; Sebikari, 2014). The entrepreneurial spirit is an essential factor that will seek to find a solution to countries' development and employment problems. There is no doubt that small business enterprises contribute tremendously to Palestinian development. Entrepreneurship constitutes a vital and considerable role in today's modern dynamic economy.

This research provided a clear overview of the main characteristics of entrepreneurs in Palestine; their motivation to becoming entrepreneurs, the challenges and obstacles of being an entrepreneur, and what has helped them the most when facing and overcoming the challenges in the business and keeping the process going, especially in this competitive and uncertain environment.

The research provided a clear picture about the insight of entrepreneurs' specific characteristics, which were mainly self-confidence, followed by their passion for seeking new opportunities, their Good Network of Professionals, Patience and Persistence, their ability to adapt to change, and finally, their Determination.

In examining the motivations for business ownership among entrepreneurs in Palestine, the results were interesting. Being their boss, along with their desire to increase income, were among the top motivators. This result supports the findings of (Chu, Benzing, \& McGee, 2007). which stated that "the motivation to be my boss and the motivation to increase income are common among entrepreneurs operating in developing nations."

The challenges and obstacles that faced entrepreneurs in starting their own business were "Lack of savings," which was rated as the most difficult challenge, followed by "political situation, "too much competition," and "The fear of risk associated with starting a business." Other medium difficulties included" Weak economic environment" and "Lack of business experience.

Therefore, to cope with the challenges and obstacles and keep businesses stable and prosperous, entrepreneurs should keep studying and gaining experience, developing the business plan, and managing financial resources and employees by finding trustworthy teams to succeed in professional counseling.

To conclude, entrepreneurs in this study rated themselves as successful and satisfied with their business success. Again, these findings are in line with the different previous studies in this field.

\section{Data availability statement}

Data available on request from the authors: The data that support the findings of this study are available from the corresponding author, [M.Y.BURBAR], upon reasonable request. 


\section{References}

Abdul Halim, M. A., Ab Aziz, W. A. W., \& Zakaria, Z. (2010). Entrepreneurial characteristics and commitment in Terengganu Heritage Industry. JM International Journal of Management Research (JMIJMR), 13-23. Retrieved November 25, 2011 from http://www.jmijitm.com/papers/130082002813-23.pdf

Abor, J., \& Adjasi, C. K. (2007). Corporate governance and the small and medium enterprises sector: theory and implications. Corporate Governance: The international journal of business in society. https://doi.org/10.1108/14720700710739769

Almeida, P. I., Ahmetoglu, G., \& Chamorro-Premuzic, T. (2014). Who wants to be an entrepreneur? The relationship between vocational interests and individual differences in entrepreneurship. Journal of Career Assessment, 22(1), 102-112. https://doi.org/10.1177/1069072713492923

Asunka, B. A. (2017). A Case for Regulating Corporate Governance for SMEs in Ghana. International Journal of Business and Management, 12(4), 168.https://doi.org/10.5539/ijbm.v12n4p168

Baidoun, S. D., Lussier, R. N., Burbar, M., \& Awashra, S. (2018). Prediction model of business success or failure for Palestinian small enterprises in the West Bank. Journal of Entrepreneurship in Emerging Economies. https://doi.org/10.1108/JEEE-02-2017-0013

Barba-Sánchez, V., \& Atienza-Sahuquillo, C., (2012). Entrepreneurial behavior: Impact of motivation factors on decision to create a new venture. Investigaciones Europeas de Dirección y Economía de la Empresa, 18(2), 132-138. https://doi.org/10.1016/S1135-2523(12)70003-5

Benzing, C., Chu, H. M., \& Szabo, B., (2005). Hungarian and Romanian entrepreneurs in Romania-motivations, problems, and differences. Journal of Global Business, 32, 77.

Berglann, H., Moen, E. R., Røed, K., \& Skogstrøm, J. F. (2011). Entrepreneurship: Origins and returns. Labor economics, 18(2), 180-193. https://doi.org/10.1016/j.labeco.2010.10.002

Berisha, G., \& Pula, J. S. (2015). Defining Small and Medium Enterprises: a critical review. Academic Journal of Business, Administration, Law and Social Sciences, 1(1), 17-28.

Bundaleska, E., Dimitrova, M., \& Nikolovska, Z. (2011). Corporate governance and small \& medium businesses.

Carsrud, A. L., \& Brännback, M. eds., (2009). Understanding the entrepreneurial mind: Opening the black box (Vol. 24). Springer Science \& Business Media. Retrieved from https://doi.org/10.1007/978-1-4419-0443-0

Chittithaworn, C., Islam, M. A., Keawchana, T., \& Yusuf, D. H. M. (2011). Factors affecting business success of small \& medium enterprises (SMEs) in Thailand. Asian social science, 7(5), 180-190. https://doi.org/10.5539/ass.v7n5p180

Chu, H. M., Benzing, C., \& McGee, C. (2007). Ghanaian and Kenyan entrepreneurs: A comparative analysis of their motivations, success characteristics, and problems. Journal of developmental entrepreneurship, 12(03), 295-322. https://doi.org/10.1142/S1084946707000691

Deakins, D., Freel, M. S., \& Mason, K. (1999). Entrepreneurship and small firms.

Doing Business. (2020). Economy Profile of West Bank and Gaza.World Bank Group

Dollinger, M. J. (1995). Entrepreneurship: Strategies and Resources (Boston, MA: Irwin).

Driessen, M. P., \& Zwart, P. S. (2006). De e-scan ondernemerstest ter beoordeling van ondernemerschap. Maandblad voor accountancy en bedrijfseconomie, $80, \quad 382$. https://doi.org/10.5117/mab.80.20829

Fong, E. Y., Jabor, M. K. B., Zulkifli, A. H., \& Hashim, M. R. (2020). September. Challenges Faced by New Entrepreneurs and Suggestions How to Overcome Them. International Conference on Student and Disable Student Development 2019 (ICoSD 2019) (pp. 223-227). Atlantis Press. https://doi.org/10.2991/assehr.k.200921.037

Gomezelj, D. O., \& Kušce, I. (2013). The influence of personal and environmental factors on entrepreneurs' performance. Kybernetes. https://doi.org/10.1108/K-08-2012-0024

Greenberg, J., \& Baron, R. A. (2008). Behavior in organizations. Upper Saddle River, N.J., Pearson Prentice Hall.

Gürol, Y., \& Atsan, N. (2006). Entrepreneurial characteristics amongst university students. Education+ training. 
https://doi.org/10.1108/00400910610645716

Hefer, Y., Cant, M. C., \&Wiid, J. A. (2015). Starting one's own business what motivates entrepreneurs? International Business \& Economics Research Journal (IBER), 14(2), 237-246. https://doi.org/10.19030/iber.v14i2.9110

Hines, J. L. (2004). Characteristics of an entrepreneur. Surgical Neurology, 4(61), 407-408. https://doi.org/10.1016/j.surneu.2003.05.004

Hisrich, R. D, Peter, M. P., \& Shepherd, D. A. (2005). Entrepreneurship (6th ed.). McGraw-Hill/Irwin.

Holt, D. H. (2000). Entrepreneurship - New Venture Creation. New Delhi: Prentice-Hall of India.

Hussain, D., \& Yaqub, M. Z. (2010). Micro-entrepreneurs: motivations, success factors, and challenges. International Research Journal of Finance and Economics, 56, $22-28$.

Kilby, P. (1971). Entrepreneurship and economic development.

Knörr, H., Alvarez, C., \& Urbano, D. (2013). Entrepreneurs or employees: a cross-cultural cognitive analysis. International Entrepreneurship and Management Journal, 9(2), 273-294. https://doi.org/10.1007/s11365-012-0235-2

Koltai, S. R. (2016). Peace through Entrepreneurship: Investing in startup culture for security and development. Brookings Institution Press.

Kongolo, M. (2010). Job creation versus job shedding and the role of SMEs in economic development. African journal of business management, 4(11), 2288-2295.

Kozubíková, L., Belás, J., Bilan, Y., \& Bartoš, P. (2015). Personal characteristics of entrepreneurs in the context of perception and management of business risk in the SME segment. Economics and Sociology. https://doi.org/10.14254/2071-789X.2015/8-1/4

Kuratko, D. F., Hornsby, J. S., \& Naffziger, D. W. (1997). An examination of owner's goals in sustaining entrepreneurship. Journal of small business management, 35(1), 24.

Kuzieva, N. R. (2017). Ways of improving the tax mechanism for small businesses and entrepreneurship in the Republic of Uzbekistan. International Journal of Physical and Social Sciences, 7(11), 15-22.

Ligthelm, A. A. (2008). A targeted approach to informal business development: the entrepreneurial route. Development Southern Africa, 25(4), 367-382. https://doi.org/10.1080/03768350802316138

McClelland, D. C., \& Mac Clelland, D. C. (1961). Achieving society (Vol. 92051). Simon and Schuster. https://doi.org/10.1037/14359-000

MENA Catalyst Foundation report. (2020). MSMEs, Start-ups and the Future of the Palestinian Economy. Retrieved from https://www.menacatalyst.ps/

Naffziger, D. W., Hornsby, J. S., \& Kuratko, D. F. (1994). A proposed research model of entrepreneurial motivation. Entrepreneurship theory and practice, 18(3), 29-42. https://doi.org/10.1177/104225879401800303

Nangoli, S., Turinawe, D. D., Kituyi, G. M., Kusemererwa, C., \& Jaaza, M. (2013). Towards enhancing business survival and growth rates in LDCS: an exploratory study of the drivers of business failure among SMEs in Kampala-Uganda. International Journal of Humanities and Social Science, 3(8), 284-291.

Nel, P., Maritz, A., \& Thongprovati, O. (2010). Motherhood and entrepreneurship: the mumpreneur phenomenon. International Journal of Organizational Innovation, 3(1), 6-34.

Nimalathasan, B. (2008). Characteristics of entrepreneurs: A comparative study of small-scale entrepreneurs of Srilankan and Bangladesh. LESIJ-Lex ET Scientia International Journal, 15(2), 350-358.

Olm, K. W., \& Eddy, G. G. (1985). Instructor's Manual to Accompany Entrepreneurship and Venture Management. CE Merrill.

Palestinian Central Bureau of Statistics (PCBS). (2019). The reality of the Private and Non-government Enterprises in Palestine.

Rafi, A., Arzu, F., Khan, W. A., ul Haq, I., \& Kashif, A. R. (2013). HEXACO model of personality traits and considerations concerning entrepreneurial performance. Asian Journal of Business Management, 5(3), 320-325.https://doi.org/10.19026/ajbm.5.5329

Reynolds, P., Bosma, N., Autio, E., Hunt, S., De Bono, N., Servais, I., ... Lopez-Garcia, P. (2005). Global 
entrepreneurship monitor: Data collection design and implementation 1998-2003. Small business economics, 24(3), 205-231.https://doi.org/10.1007/s11187-005-1980-1

Robichaud, Y., McGraw, E., \& Alain, R., (2001). Toward the development of a measuring instrument for entrepreneurial motivation. Journal of developmental entrepreneurship, 6(2), 189.

Sean Bryant. (2020). How Many Startups Fail and Why?. Received from HTTP: Retrieved from https://www.investopedia.com/articles/personal-finance/040915/how-many-startups-fail-and-why.asp\#: :te $\mathrm{xt}=\mathrm{In} \% 202019 \% 2 \mathrm{C} \% 20$ the \%20failure\%20rate, 70\%25\%20in\%20their\%2010th\%20year

Sebikari, K. V. (2014). Critical analysis of the taxation policy on small businesses and entrepreneurial enterprises in Uganda. Journal of Economics and Sustainable Development, 5(10), 12-19.

Shaver, K. G., \& Scott, L. R. (1992). Person, process, choice: The psychology of new venture creation. Entrepreneurship theory and practice, 16(2), 23-46.https://doi.org/10.1177/104225879201600204

Sitharam, S., \& Hoque, M. (2016). Factors affecting the performance of small and medium enterprises in KwaZulu-Natal, South Africa. Problems and perspectives in Management, 14(2), 277-288. https://doi.org/10.21511/ppm.14(2-2).2016.03

Wilson, P. (2020), Opportunities and Challenges in Implementing a Cluster-Based Economic Development strategy in the Palestinian Context, in Light of International Experiences and National Development Priorities.

Yalcin, S., \& Kapu, H. (2008). Entrepreneurial dimensions in transitional economies: A review of relevant literature and the case of Kyrgyzstan. Journal of Developmental Entrepreneurship, 13(02), 185-204. https://doi.org/10.1142/S1084946708000922

Yimamu, N. (2018). Entrepreneurship and Entrepreneurial Motivation. Journal Buisness Management. Centria University of Applied Sciences.

Zimmerer, T. W., \& Scarborough, N. M. (1998). Essentials of entrepreneurship and small business management. Prentice-Hall.

Zimmerman, M. A., \& Chu, H. M. (2013). Motivation, success, and problems of entrepreneurs in Venezuela. Journal of Management Policy and Practice, 14(2), 76-90.

\section{Copyrights}

Copyright for this article is retained by the author(s), with first publication rights granted to the journal.

This is an open-access article distributed under the terms and conditions of the Creative Commons Attribution license (http://creativecommons.org/licenses/by/4.0/). 